\title{
Metabolism of Cold-Stored Pancreatic Islets
}

\author{
Barbara J. Franke1 ${ }^{1}$, E. Gylfe ${ }^{2}$, B. Hellman ${ }^{2}$, L.-Å. Idahl, U. Landström, S. Løvtrup, and J. Sehlin \\ Department of Histology and Department of Zoophysiology, University of Umeă, Sweden
}

Summary. A previous study showed that the ability of glucose to stimulate insulin release was retained in islets stored at $8^{\circ} \mathrm{C}$ for one week provided that glucose was present in a high concentration in the storage medium. The metabolic properties of islets stored in the cold have now been further explored in an attempt to clarify the protective effect of glucose. During storage in the cold the islet formation of ${ }^{3} \mathrm{H}_{2} \mathrm{O}$ from $\left(5-{ }^{3} \mathrm{H}\right)$ glucose and oxygen consumption were only a few per cent of that of fresh islets whereas the uptake of ${ }^{86} \mathrm{Rb}^{+}$was $20-48 \%$. Rewarming the cold-stored islets to $37^{\circ} \mathrm{C}$ after one week of cold-storage restored the ${ }^{86} \mathrm{Rb}^{+}$uptake, the formation of ${ }^{3} \mathrm{H}_{2} \mathrm{O}$ and ${ }^{14} \mathrm{CO}_{2}$ from labelled glucose and oxygen consumption to $75,80,60$ and $40 \%$ respectively of fresh islet levels. The results emphasize the usefulness of cold-storage for preservation of functionally intact isolated islets.

Key words: Pancreatic islets, cold-storage, culture, glucose utilization, oxygen consumption, ${ }^{86} \mathrm{Rb}^{+}$. uptake, metabolism.

Methods for preservation of functionally intact pancreatic islets may be of great importance for future treatment of diabetes mellitus in allowing transplantation of large amounts of islets. It was evident from a previous study [1] that glucose-stimulated insulin release decreased when the microdissected islets

\footnotetext{
1 On leave from the Metabolic Research Unit, 1143 HSW, University of California, San Francisco, CA 94143, USA

2 Present address: Department of Histology, University of Uppsala, Uppsala, Sweden
}

were stored for one week at $37^{\circ} \mathrm{C}$, but that functional integrity could be maintained by storage at $8{ }^{\circ} \mathrm{C}$. Successful maintenance of glucose-stimulated release, required the presence of glucose at a high concentration in the storage medium. The purpose of the present work was to study the effect of temperature reduction on islet metabolic activity. We have therefore measured the islet production of ${ }^{3} \mathrm{H}_{2} \mathrm{O}$ and ${ }^{14} \mathrm{CO}_{2}$ from labelled glucose, the uptake of ${ }^{86} \mathrm{Rb}^{+}$and consumption of oxygen before, during and after cold storage.

\section{Materials and Methods}

\section{Chemicals}

Reagents of analytical grade and deionized water were used throughout. The chemicals and their sources were as follows. N-2hydroxyethyl-piperazine-N-2-ethanesulfonic acid (Hepes) and bovine serum albumin (fraction V) from Sigma Chemical Co., St. Louis, Mo., USA; tissue Culture Medium 199 (TCM 199, 10X concentrated) from Statens bakteriologiska laboratorium, Stockholm, Sweden; benzylpenicillin from AB Kabi, Stockholm, Sweden; gentamicin from Schering Corp., Kenilworth, N. J., USA; crystalline mouse insulin from Novo $\mathrm{A} / \mathrm{S}$, Copenhagen, Denmark; ${ }^{125}$ I-insulin from Farbwerke Hoechst A. G., Frankfurt/M., FRG; ${ }^{86} \mathrm{RbC1},\left(6,6^{\prime}-{ }^{3} \mathrm{H}\right)$-sucrose, D-(U-14 $\left.\mathrm{C}\right)$ glucose and $\mathrm{D}-\left(5_{-}{ }^{3} \mathrm{H}\right)$-glucose from The Radiochemical Centre, Amersham, England.

\section{Media}

The basal medium consisted of modified TCM 199 with Hanks' salts containing $25 \mathrm{mmol} / 1$ Hepes, but lacking phenol red and glucose. This medium was supplemented with $1 \mathrm{mg} / \mathrm{ml}$ bovine serum albumin and $1-40 \mathrm{mmol} / 1$ glucose. All storage media contained $50 \mu \mathrm{g} / \mathrm{ml}$ benzylpenicillin, and the media used for oxygen consumption studies also contained $50 \mu \mathrm{g} / \mathrm{ml}$ gentamicin. Albumin was excluded from the incubation media when measuring ${ }^{3} \mathrm{H}_{2} \mathrm{O}$ or ${ }^{14} \mathrm{CO}_{2}$ production and ${ }^{86} \mathrm{Rb}^{+}$uptake. 


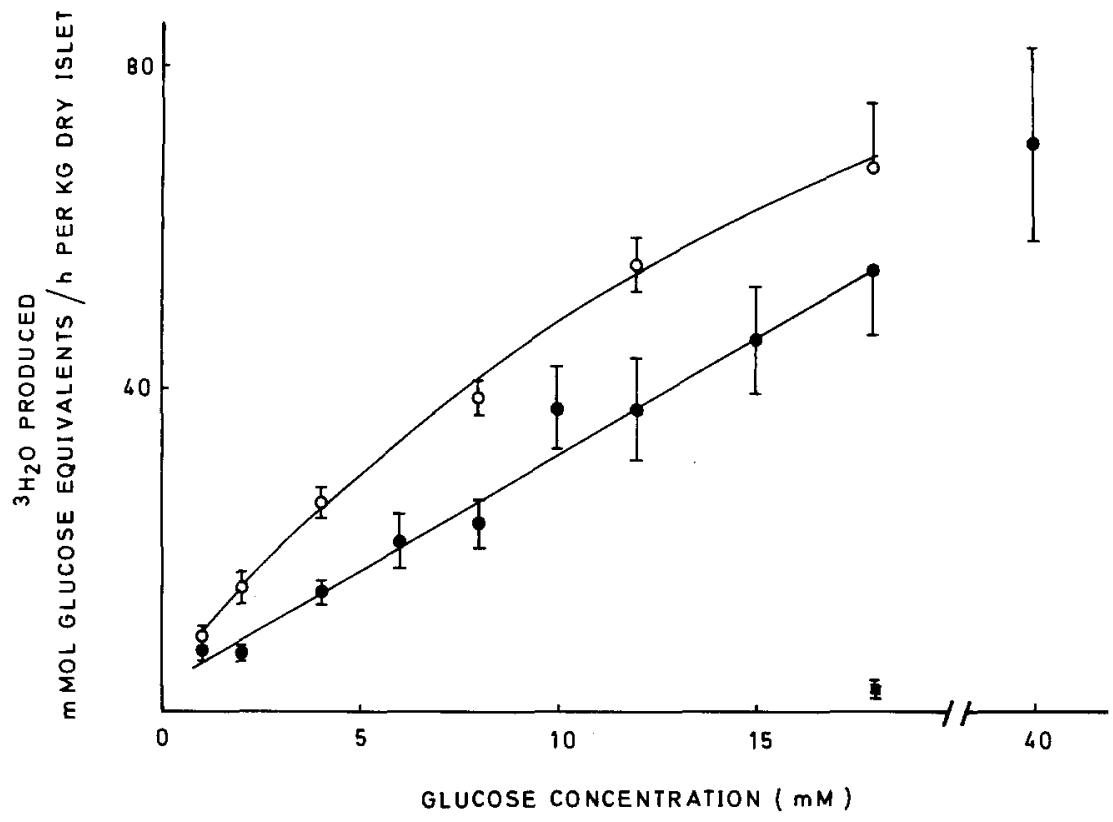

Fig. 1. Production of ${ }^{3} \mathrm{H}_{2} \mathrm{O}$ from $\mathrm{D}$ - $(5-$ $\left.{ }^{3} \mathrm{H}\right)$ glucose in fresh islets and in islets stored for 1 week at $8^{\circ} \mathrm{C}$. The results are expressed as mmoles of glucose equivalents metabolized $/ \mathrm{h} / \mathrm{kg}$ dry islet. Each point represents the mean value \pm SEM for 4-9 experiments (animals). Fresh islets $(\mathrm{O})$ were first preincubated for $60 \mathrm{~min}$ at $37^{\circ} \mathrm{C}$ in $1 \mathrm{ml}$ medium containing $1 \mathrm{mmol} / 1$ glucose and then incubated for $60 \mathrm{~min}$ at the same temperature in $15 \mu \mathrm{l}$ medium with $1-40 \mathrm{mmol} / 1 \mathrm{D}-\left(5-{ }^{3} \mathrm{H}\right)$ glucose $(0.25-10.0 \mathrm{Ci} / \mathrm{mol})$. Islets stored at $8{ }^{\circ} \mathrm{C}(\bullet)$ were incubated for 4 hours at $37^{\circ} \mathrm{C}$ in medium containing $18 \mathrm{mmol} / 1$ glucose prior to the preincubation and incubation periods as above. In one series of experiments the production of ${ }^{3} \mathrm{H}_{2} \mathrm{O}$ from stored islets was measured during $3-5$ hours at $8^{\circ} \mathrm{C}$ without preceding incubations at $37^{\circ} \mathrm{C}(\mathbf{\square})$
Table 1. Production of ${ }^{14} \mathrm{CO}_{2}$ from $\mathrm{D}-\left(\mathrm{U}-{ }^{14} \mathrm{C}\right)$ glucose in fresh islets and in islets stored for 1 week at $8{ }^{\circ} \mathrm{C}$

\begin{tabular}{llll}
\hline \multirow{2}{*}{ Type of islets } & \multicolumn{3}{l}{ Glucose concentration (mmol/1) } \\
\cline { 2 - 4 } & & 18 & Difference \\
\hline Fresh islets & $1.1 \pm 0.1$ & $26.2 \pm 3.5$ & $25.1 \pm 3.5^{\mathrm{a}}$ \\
& $(10)$ & $(10)$ & $(10)$ \\
Cold-stored islets & $1.2 \pm 0.2$ & $15.4 \pm 1.4$ & $14.3 \pm 1.5^{\mathrm{a}}$ \\
& $(12)$ & $(11)$ & $(11)$ \\
\hline
\end{tabular}

The results are expressed as mmoles of glucose equivalents metabolized $/ \mathrm{h} / \mathrm{kg}$ dry islet and given as mean values \pm SEM for the number of experiments (animals) given within parentheses. Fresh islets were first preincubated for $60 \mathrm{~min}$ at $37^{\circ} \mathrm{C}$ in $1 \mathrm{ml}$ medium containing $1 \mathrm{mmol} / 1$ glucose and incubated for $60 \mathrm{~min}$ at the same temperature in $100 \mu \mathrm{l}$ medium with $1(17.1 \mathrm{Ci} / \mathrm{mol})$ or $18 \mathrm{mmol} / 1 \quad(1.0 \mathrm{Ci} / \mathrm{mol}) \mathrm{D}-\left(\mathrm{U}-{ }^{14} \mathrm{C}\right)$ glucose. Islets previously stored at $8{ }^{\circ} \mathrm{C}$ were kept for 4 hours at $37^{\circ} \mathrm{C}$ in a medium containing $18 \mathrm{mmol} / 1$ glucose prior to the preincubation and incubation periods as above

${ }^{\mathrm{a}} \mathrm{P}<0.001$

\section{Animals and Microdissection of Islets}

Male obese-hyperglycaemic mice (gene symbol ob/ob) 8-10 months old, were taken from the Umeå colony [2]. After fasting overnight, the animals were killed by decapitation under ether anaesthesia and fresh pancreatic islets were microdissected [3] from the pancreas at room temperature in medium containing $1 \mathrm{mmol} / 1$ glucose.

\section{Storage, Incubation and Weighing of Islets}

Storage of islets was performed for 7 days at $8{ }^{\circ} \mathrm{C}$ in a medium containing $18 \mathrm{mmol} / 1$ glucose as described previously [1]. For studies of oxygen consumption, islets were stored at $8{ }^{\circ} \mathrm{C}$ for $5-7$ days. Islets stored in the cold were usually incubated for 4 hours at $37^{\circ} \mathrm{C}$ in storage medium before further incubation periods. ${ }^{3} \mathrm{H}_{2} \mathrm{O}$ production, ${ }^{86} \mathrm{Rb}$ uptake and $\mathrm{O}_{2}$ consumption were also studied in the cold without a prior period at $37^{\circ} \mathrm{C}$. Measurements of ${ }^{3} \mathrm{H}_{2} \mathrm{O}$ and ${ }^{14} \mathrm{CO}_{2}$ production were preceded by a preincubation period as described in the legends to Figure 1 and Table 1, and the $\mathrm{O}_{2}$ consumption studies were preceded by an equilibration period. The incubation procedures, stated in the legends to the Tables and Figures, were similar to those previously described for measurement of the rates of ${ }^{14} \mathrm{CO}_{2}$ production [4], ${ }^{3} \mathrm{H}_{2} \mathrm{O}$ production [5], ${ }^{86} \mathrm{Rb}$ uptake [6] and $\mathrm{O}_{2}$ consumption [7]. After incubation, the islets were placed on pieces of aluminium foil and gently freed of as much contaminating fluid as possible with the aid of a micropipette. After freeze-drying overnight $\left(-40^{\circ} \mathrm{C}, 0.1 \mathrm{~Pa}\right)$, the islets were weighed on a quartz fibre balance [8].

\section{Analytical Procedures}

The methods for determining ${ }^{14} \mathrm{CO}_{2}[4]$ and ${ }^{3} \mathrm{H}_{2} \mathrm{O}$ production [5], ${ }^{86} \mathrm{Rb}$ uptake [6] and $\mathrm{O}_{2}$ consumption [7] have been described previously.

\section{Statistics}

Statistical significance was estimated from the difference between paired test and control data using the two-tailed Student distribution.

\section{Results}

The islet production of ${ }^{3} \mathrm{H}_{2} \mathrm{O}$ from $\left(5-{ }^{3} \mathrm{H}\right)$ glucose is shown in Figure 1. In fresh islets ${ }^{3} \mathrm{H}_{2} \mathrm{O}$ formation increased from 9.6 to $67.3 \mathrm{mmol}$ glucose equivalents/ $\mathrm{h} / \mathrm{kg}$ dry islet between 1 and $18 \mathrm{mmol} / 1$ glucose. The ${ }^{3} \mathrm{H}_{2} \mathrm{O}$ production at $8{ }^{\circ} \mathrm{C}$ in $18 \mathrm{mmol} / 1$ glucose was measured after storage at this temperature for one week and found to be only $3.0 \mathrm{mmol}$ glucose equivalents $/ \mathrm{h} / \mathrm{kg}$ dry islet. Warming the cold-stored islets for 4 hours at $37{ }^{\circ} \mathrm{C}$ restored ${ }^{3} \mathrm{H}_{2} \mathrm{O}$ formation at $18 \mathrm{mmol} / 1$ glucose to about $80 \%$ that of fresh islets. 
The glucose concentration dependency was similar to that of fresh islets.

Table 1 shows the islet production of ${ }^{14} \mathrm{CO}_{2}$ from D- $\left(\mathrm{U}-{ }^{14} \mathrm{C}\right)$ glucose. Similar rates of ${ }^{14} \mathrm{CO}_{2}$ production were noted both in fresh and cold stored islets at $1 \mathrm{mmol} / 1$ glucose, whereas at $18 \mathrm{mmol} / 1$ glucose the ${ }^{14} \mathrm{CO}_{2}$ production of cold stored islets was reduced to about $60 \%$ that of fresh islets.

Oxygen consumption data are presented in Table 2 . Fresh islets incubated with $18 \mathrm{mmol} / 1$ glucose consumed $20.41 \mathrm{O}_{2} / \mathrm{h} / \mathrm{kg}$ dry islet at $37^{\circ} \mathrm{C}$. Storage for $5-7$ days at $8^{\circ} \mathrm{C}$ reduced oxygen consumption at $37^{\circ} \mathrm{C}$ to $40 \%$ of that of fresh islets. At $8^{\circ} \mathrm{C}$ fresh islets consumed only $7 \%$ of the consumption at $37^{\circ} \mathrm{C}$. This figure was further reduced to $4 \%$ after storage in the cold.

Figure 2 shows the islet uptake of ${ }^{86} \mathrm{Rb}^{+}$as a function of time. Maximal levels of rubidium uptake were reached between 60 and $120 \mathrm{~min}$ in fresh islets at $37^{\circ} \mathrm{C}$. The $120 \mathrm{~min}$ level represents a 52 fold accumulation. After 4 hours or 1 week of cold-storage, ${ }^{86} \mathrm{Rb}$-uptake levels were $48 \%$ and $20 \%$ that of fresh islets respectively. Warming the islets stored in the cold for 1 week to $37^{\circ} \mathrm{C}$ restored the ${ }^{86} \mathrm{Rb}^{+}$uptake to $75 \%$ of the fresh islet levels.

\section{Discussion}

In a previous study a procedure was established for keeping pancreatic islets functionally intact for long periods of time [1]. After one week at $8{ }^{\circ} \mathrm{C}$ followed by a 4-hour period at $37^{\circ} \mathrm{C}$ glucose stimulated insulin release to the same extent as in freshly dissected islets. Despite the low temperature a high glucose concentration in the storage medium was mandatory for preservation of function. The protective effect of glucose was probably not a result of an interaction with transport carriers in the B-cell membrane, since high concentrations of 3-0-methyl glucose, which shares a common transport mechanism with glucose [9], did not maintain B-cell function (not shown).

Cold stored islets have now been further characterized with respect to the role of glucose during storage. The formation of ${ }^{3} \mathrm{H}_{2} \mathrm{O}$ from $\mathrm{D}-\left(5-{ }^{3} \mathrm{H}\right)$ glucose was used as a measure of the combined flux through the glycolytic and phosphogluconate pathways [10], and the formation of ${ }^{14} \mathrm{CO}_{2}$ from $\mathrm{D}-\left(\mathrm{U}-{ }^{14} \mathrm{C}\right)$ glucose was used as an indicator of the aerobic degradation of glucose. The total oxidative metabolism of the pancreatic islets was studied by measuring oxygen consumption with an automatic electromagnetic respirometer [7], and ${ }^{86} \mathrm{Rb}^{+}$was used as a functional analogue to study the islet ability to concentrate $\mathrm{K}^{+}$ [6]. Since all measurements were performed in TCM 199 , it is of interest to compare the control data obtained with fresh islets at $37^{\circ} \mathrm{C}$ to previously pub-
Table 2. Oxygen consumption of fresh islets and islets stored for $5-7$ days at $8{ }^{\circ} \mathrm{C}$

\begin{tabular}{llr}
\hline & \multicolumn{2}{l}{ Temperature ${ }^{\circ} \mathrm{C}$} \\
\cline { 2 - 3 } Type of islets & & \multicolumn{1}{l}{37} \\
\hline Fresh islets & $1.4 \pm 0.1$ & $20.4 \pm 3.2$ \\
Cold stored islets & $0.8 \pm 0.2$ & $7.7 \pm 2.2$ \\
\hline
\end{tabular}

The results are expressed as $1 \mathrm{O}_{2} / \mathrm{h} / \mathrm{kg}$ dry islet under normal conditions (NTP) and given as mean values of 5 expermiments \pm SEM. Islets were placed in respiration chambers containing 20-30 $\mu \mathrm{l}$ medium supplemented with $18 \mathrm{mmol} / 1$ glucose. The chambers were placed in an automatic electromagnetic respirometer (7) and after an equilibration period of $2-5$ hours the mean oxygen consumption during 3 hours at $37^{\circ} \mathrm{C}$ or 5 hours at $8{ }^{\circ} \mathrm{C}$ was determined

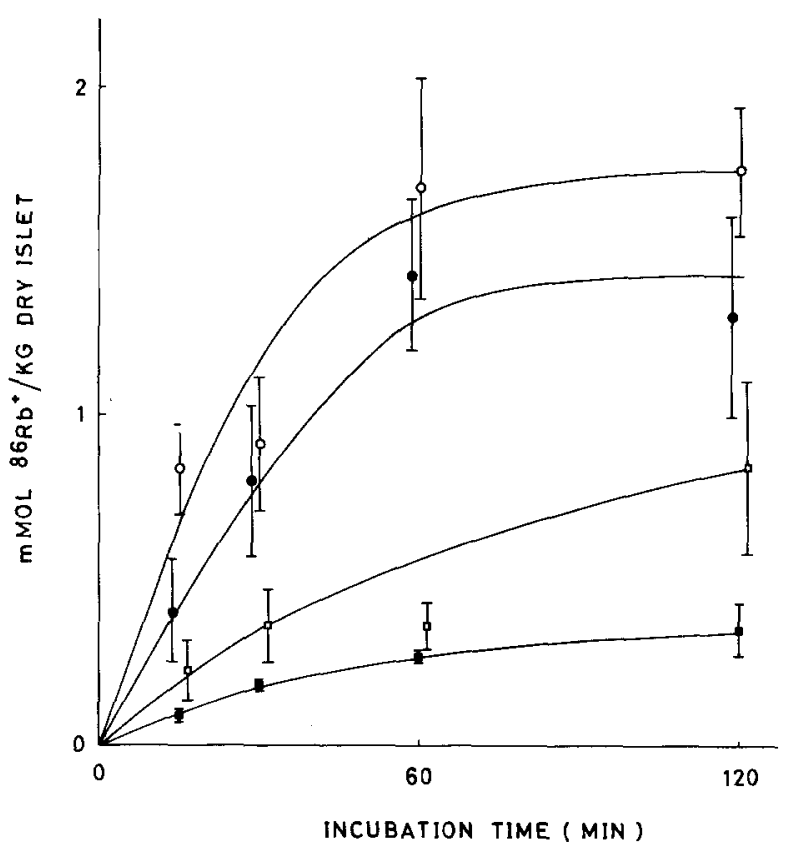

Fig. 2. Uptake of $\mathrm{Rb}^{+}$with time in fresh islets $(O, \square)$ and in islets stored for 1 week at $8{ }^{\circ} \mathrm{C}(\boldsymbol{\square}) . \mathrm{Rb}^{+}$values in excess of the sucrose space are given as the mean values \pm SEM for $3-4$ experiments (animals). The islets were first incubated for $4 \mathrm{~h}$ in medium containing $18 \mathrm{mmol} / \mathrm{l}$ glucose, and then incubated for $15,30,60$ or $120 \mathrm{~min}$ in the same type of medium supplemented with $28 \mu \mathrm{mol} / 1$ ${ }^{86} \mathrm{RbCl}(710 \mathrm{Ci} / \mathrm{mol})$ and $100 \mu \mathrm{mol} / 1 /\left(6,6^{\prime}-{ }^{3} \mathrm{H}\right)$ sucrose $(150 \mathrm{Ci} /$ $\mathrm{mol})$. The temperature during the incubation periods was either $37^{\circ} \mathrm{C}(\mathrm{O}, \boldsymbol{\theta})$ or $8^{\circ} \mathrm{C}(\square, \mathbf{\square})$

lished observations in less complex media. As might be expected, the present rate of ${ }^{14} \mathrm{CO}_{2}$ formation was almost $50 \%$ lower or reduced by $20-25 \mathrm{mmol}$ glucose equivalents/hour/ $\mathrm{kg}$ dry islet when compared to islets incubated with $18 \mathrm{mmol} / 1$ glucose as the only substrate [11]. A similar comparison of the formation of ${ }^{3} \mathrm{H}_{2} \mathrm{O}$ revealed a reduction of the same magnitude from about 95 [5] to about $70 \mathrm{mmol}$ glucose equivalents metabolized/hour $/ \mathrm{kg}$ dry islet. Another difference in the ${ }^{3} \mathrm{H}_{2} \mathrm{O}$ production at various glucose con- 
centrations was the lack of an apparent sigmoidal dose-response relationship. Since this relationship has been found to depend on oxygen tension [5], use of ambient air as gas phase instead of $95 \% \mathrm{O}_{2} / 5 \%$ $\mathrm{CO}_{2}$ may explain the absence of a sigmoidal relationship. However, it should be noted that a clearly sigmoidal dose-response relationship has been found for glucose-stimulated insulin release under identical conditions both in fresh [12] and cold-stored islets [1]. Oxygen consumption was almost 2.5 times greater in TCM 199 than has previously been observed with Krebs-Ringer-phosphate buffer [13]. A control experiment with phosphate buffer indicated that this discrepancy could largely be explained by the different media. Uptake of ${ }^{86} \mathrm{Rb}^{+}$was the only measured variable which did not differ much from previously published data [6] suggesting that there is a characteristic ionic equilibrium for functioning pancreatic B-cells.

After storage at $8{ }^{\circ} \mathrm{C}$ and a 4 hour rewarming period at $37^{\circ} \mathrm{C}$ the ${ }^{86} \mathrm{Rb}^{+}$uptake, ${ }^{3} \mathrm{H}_{2} \mathrm{O}$ formation, ${ }^{14} \mathrm{CO}_{2}$ formation and oxygen consumption of the islets were maintained at $75,80,60$ and $40 \%$ of the fresh islet levels. The recoveries of below $100 \%$ may indicate decreased viability. However, such a decrease cannot be large since glucose-stimulated insulin release was fully maintained after cold-storage [1]. The total aerobic metabolism was drastically reduced after cold-storage, whereas that of glucose was less affected. Since glucose may stimulate insulin secretion by being metabolized via the glycolytic pathway $[11,14-16]$ it is particularly interesting to note that glycolysis was less affected by cold-storage than aerobic breakdown of glucose. The preservation of glucose-stimulated insulin release after cold-storage is thus consistent with the good maintenance of ${ }^{3} \mathrm{H}_{2} \mathrm{O}$ production.

The metabolism and ${ }^{86} \mathrm{Rb}^{+}$-accumulating ability of islets were studied at $8{ }^{\circ} \mathrm{C}$. Whereas the ability to accumulate ${ }^{86} \mathrm{Rb}^{+}$severalfold was largely retained, the islet formation of ${ }^{3} \mathrm{H}_{2} \mathrm{O}$ from $\left({ }^{5-}{ }^{3} \mathrm{H}\right)$ glucose and the oxygen consumption were reduced to only a few per cent of the values at $37^{\circ} \mathrm{C}$. Thus, it appears that metabolism, although strongly reduced, can maintain ${ }^{86} \mathrm{Rb}^{+}$pumping into the islet cells at $8{ }^{\circ} \mathrm{C}$.

A high concentration of glucose is necessary to maintain the B-cell sensitivity to glucose as stimulator of insulin release whether the islets have been stored at $8^{\circ} \mathrm{C}$ [1] or cultured at $37^{\circ} \mathrm{C}[12,17]$. This observation together with the present data lend some support to the suggestion that the protective effect of glucose is due to interaction with a specific glucoreceptor in the B-cells rather than its function as a metabolic fuel [17].

The present studies suggest that storage at $8{ }^{\circ} \mathrm{C}$ is an useful technique for preserving glucose-stimulated insulin release from isolated pancreatic islets by reversibly decreasing cellular metabolism.
Acknowledgements. This work was supported by the Swedish Medical Research Council (12x-562) and the Swedish Diabetes Association.

\section{References}

1. Frankel, B. J., Gylfe, E., Hellman, B., Idahl, L.-A.: Maintenance of insulin release from pancreatic islets stored in the cold for up to 5 weeks. J. Clin. Invest. 57, 47-52 (1976)

2. Hellman, B.: Studies in obese-hyperglycemic mice. Ann. N. Y. Acad. Sci. 131, 541-558 (1965)

3. Hellerström, C.: A method for the microdissection of intact pancreatic islets of mammals. Acta Endocrinol (Kbh.) 45, 122-132 (1964)

4. Hellman, B., Sehlin, J., Täljedal, I.-B.: Effects of glucose and other modifiers of insulin release on the oxidative metabolism of amino acids in microdissected pancreatic islets. Biochem. J. 123, 513-521 (1971)

5. Hellman, B., Idahl, L.- $\AA$., Sehlin, J., Täljedal, I.-B.: Influence of anoxia on glucose metabolism in pancreatic islets: lack of correlation between fructose-1,6-disphosphate and apparent glycolytic flux. Diabetologia 11, 495-500 (1975)

6. Sehlin, J., Täljedal, I.-B.: Transport of rubidium and sodium in pancreatic islets. J. Physiol. (Lond.) 242, 505-515 (1974)

7. Landström, U., Løvtrup, S.: Oxygen consumption of normal and dwarf embryos of xenopus laevis. Wilhelm Roux' Arch. 176, 1-12 (1974)

8. Lowry, O. H.: The quantitative histochemistry of the brain. J. Histochem. Cytochem. 1, 420-428 (1953)

9. Hellman, B., Sehlin, J., Täljedal, I.-B.: Transport of 3-Omethyl-D-glucose into mammalian pancreatic $\beta$-cells. Pfluegers Arch. 340, 51-58 (1973)

10. Ashcroft, S. J. H., Weerasinghe, L. C. C., Bassett, J. M., Randle, P. J.: The pentose cycle and insulin release in mouse pancreatic islets. Biochem. J. 126, 525-532 (1972)

11. Hellman, B., Idahl, L.-Å., Lernmark, Å., Sehlin, J., Täljedal, I.-B.: The pancreatic $\beta$-cell recognition of insulin secretagogues. Effects of calcium and sodium on glucose metabolism and insulin release. Biochem. J. 138, 33-45 (1974)

12. Buitrago, A., Gylfe, E., Hellman, B., Idahl, L.-A., Johansson, M.: Function of microdissected pancreatic islets cultured in a chemically defined medium. I. Insulin content and release. Diabetologia 11, 535-540 (1975)

13. Hellerström, C.: Effects of carbohydrates on the oxygen consumption of isolated pancreatic islets of mice. Endocrinology 81, 105-112 (1967)

14. Ashcroft, S. J. H., Hedeskov, C. J., Randle, P. J.: Glucose metabolism in mouse pancreatic islets. Biochem. J. 118, 143-154 (1970)

15. Malaisse, W. J., Sener, A., Koser, M., Herchuelz, A.: Stimulus-secretion coupling of glucose-induced insulin release. Metabolism of $\alpha$ and $\beta$-D-glucose in isolated islets. J. Biol. Chem. 251, 5936-5943 (1976)

16. Malaisse, W. J., Sener, A., Koser, M., Ravazzola, M., Malaisse-Lagae, F.: The stimulus-secretion coupling of glucose-induced insulin release. Insulin release due to glycogenolysis in glucose-deprived islets. Biochem. J. 164, 447-454 (1977)

17. Gylfe, E.: Specific glucose protection of pancreatic $\beta$-cell function during culture in chemically defined medium. Endocrinology 101, 1281-1285 (1977)

Received: January 5, 1978,

and in revised form: April 14, 1978

Dr. E. Gylfe

Department of Histology

University of Uppsala

Biomedicum

Box 571

S-751 23 Uppsala

Sweden 